doi:10.7592/FEJF2011.47.panina

\title{
FORMULAE FOR EXPELLING ILLNESSES/ DISEASES IN UDMURT CHARMS AND PRAYERS
}

\section{Tatiana Panina}

\begin{abstract}
The article is devoted to Udmurt healing charms (pel'l'as'kon) and traditional prayers (kuris'kon) which have been collected since the 18 th century. The living tradition of charming is still considered to be one of the effective ways of fighting with different diseases and weird spirits which cause abnormal conditions both in people and livestock. Available magic texts of folklore allow the revelation of the principles of resistance to diseases and evil spirits and consider them as the representatives of the other world. These conclusions are made on the basis of the analysis of special formulae which are aimed at expelling the illness/disease from the human body and the local environment.
\end{abstract}

Key words: charms and prayers, formula for expelling illness/disease, Udmurt folklore, weird character of the illness/disease

Typology of formulae which contain the idea of sending illnesses away has been studied in detail by Russian and foreign researchers in a number of articles devoted to sacral texts of Slavic (Russian, Ukrainian, Belorussian, Polish, Bulgarian, Czech), West Romanic (French) and Baltic (Lettish) traditions (Sveshnikova 1993, 1995; Olupe 1993; Vel'mezova 2000; Nebzhegovskaia-Bartminskaia 2005). Comparative analysis of different traditions allows us to reveal some specific features in describing the space of charms (Sveshnikova 1993; Vel'mezova 1999). Thus, Ekaterina Vel'mezova comes to a conclusion that, in Russian charms, the world has a multi-level structure, in Czech charms it is represented as a two-level space, and in French sacral texts the space is extremely reduced (Vel'mezova 1999: 54).

Likewise, it would also be interesting to study the formulae of expelling illness/disease in one of the Finno-Ugric cultures - the Udmurt tradition. Mythological conception of illness in the mentioned tradition has already been researched by some ethnographers (Vladykin 1994; Minniiakhmetova 2003; Nikitina 2003; Zaitseva 2004). Taking into consideration that one of the most important features of the text is its ability to pass on and keep information, I analyse a collection of magical texts to find out more about the worldview of 
the Udmurts, with focus on Udmurt charms (pel'l'as'kon / pel'l'as'kon kyl) and prayers (kuris'kon). For this purpose, approximately 400 sacral texts, written since the 18th century, were examined, published in different editions, and held in the archives of the Udmurt Institute of History, Language and Literature (Russian Academy of Sciences, Ural Department), folklore and dialectological archives of the Faculty of Udmurt Philology (Udmurt State University) and the Philological Faculty (Glazov State Pedagogical Institute). In addition, some charms have been recorded by the author during her scientific expeditions since 2003.

According to the Udmurt healing charms, illness or the spirit of illness can penetrate into the human body and start "eating" it from within. The terms which are used to address the illness emphasise its hostile status toward people-tushmon ('the enemy, evil spirit'), tushmon-aman ('the enemy, the fiend'):

Сизьымдон но сизьым дас сизьым пӧртэм ошмесэз огаӟе карны быгатӥд ке, валлань кошкись карны быгатӥд ке, собере, тушмон, си-ю та адямиэз!

If you are able to join seventy seven, seventeen different springs and turn their stream back then you, the enemy, eat and drink this person! (Munkácsi 1887: 184-185)

Уллань кошкысь вуэз йырад понон изьы лэсьтыса-карса нуллыны лутод ке - сотэк уг сётӥськы мон тӧныд сины-юны!

If you are able to turn the river flowing down into a hat and to wear it otherwise I don't allow/give you to eat and drink (this patient!) (Munkácsi 1952: 156-157)

The analysis of the Udmurt healing charms shows that the motif of eating a patient is common for those texts which were supposed to treat wasting disease (the result of putting an evil eye on a person). Most likely, it can be explained by way of the mythological perception of illness by the Udmurts: severe unknown illnesses/diseases were considered to be caused by the negative influence of evil sorcerers. In those cases a patient could languish and waste away in a short period of time. The anxiety associated with this was the reason why the Udmurts sought the help of superior gods, their prayers expressed the request to protect the people from that kind of negative influence:

Тушмонлы-аманлы эн сёт, Инмаре! Зарни кенерен, азвесь кенерен тушмон-аманлэсь уть-ворды, Инмаре!

Don't give us to the enemy/the fiend, God Inmar! Enclose us within a gold fence, a silver fence/save us from the enemy, God Inmar! (Munkácsi 1887: 151) 
Тушмонлы-аманлы эн сёт! Олокин “сиё-юоо” пуоз, солы эн сёт! Олокӧйе шукед-шагед вань, олокӧӥе калераед вань, эн сёт!

Don't give us to the enemy! Someone will say: "I'll eat and drink", don't give us him/her! You [Inmar] have different illnesses, you have different contagious diseases, don't give us [them]! (Munkácsi 1887: 149)

The illness was ordered to leave the body the same way it had entered:

Кытй пырид, отӥ потса кошкы та адями бордысь, тьфу! Та верам кылы-буры эм мед луоз та адямилы!

Where you've entered this person there leave him/her, pah! May these words said by me be medicine/cure for this person! (Munkácsi 1952: 157-160)

Рось-грось, мылегун, бекбекут, куштэм кут, дюруктэм, погань, татын эн ветлы мон дорам бейлэныса, касланса! Кытӥ ке пырид, отй потыса кошкы! Пыремтӥетӥд (потса кошкы)!

Ros'-gros', myl'egun, bekbekut, d'uruktem, pogan' [allegorical words describing/cursing the devil], don't come to me, thinking of hurting! Where you've entered there leave! There you've entered (leave)! (Munkácsi 1952: 160-161)

Куинь сюреслэн куттӥз лыктэм, отӥ мед кошкоз!

Which of the three ways it has come there let it leave! (Wichmann 1893: 176-177)

Тӧлысь вуид - тӧлэ ик кошкы, калыкысь вуид - калыке ик кошкы! If you've been brought with the wind, go away with the wind, if you've come from people, go away to the people! (FD UdSU 2003/2004 N. Eshmakova, p. 10).

According to the ancient people's logic the surrounding environment was divided into two parts: "this world" (the world of people) and "the other world" (the weird world, the beyond). Like other peoples, the Udmurts thought that an illness/disease/unhealthy condition was caused by the supernatural beings - representatives of "the other world". The spirit of illness was considered to be one of these beings, which breaks into this world and thereby shatters the order and stability of the objective reality. To re-establish the disturbed harmony, it was necessary to return the spirit to the beyond. For this purpose during the process of healing the sorcerer appealed to the evil spirits peri and asked them to take the illness back with them to the next world: 
Качиен но венен ӟус вылэ но вырӟем интые кирос пуктоно но собере верано:

Кыр пери,

Акшан пери,

ӵукна пери,

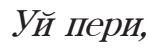

Нуназе пери,

Вань висёнзэ басьтэлэ.

Using scissors and a needle one should make the sign of the cross over the bench and painful site (lit. site/part of a body/organ that was "pulled off", i.e. lost its common position) and say:

The spirit of an open space,

The spirit of the dusk,

The spirit of the morning,

The spirit of the night,

The spirit of the afternoon,

Take away all his/her diseases/illnesses.

(FA UdSU, FE-1975, c. 5, s. 17)

The Udmurts appealed not only to the spirits but could also ask deities for help:

Ву мумы, чылкытаты пимес, сякой приччалэсь-висёнлэсь чылкытаты пимес!

Water mother, clean our son, from any illnesses/disorders clean our son! (FD UdSU 1999/2000 E. Lozhkina, p. 30)

or the God Inmar:

Куке ықжголэн вирез потоз, соку, Инмаре, сёт монэ вединлы сиыны!

When fleece bleeds, then, Inmar, give me to an evil sorcerer for eating! (Archive of UIHLL f. 749, c. 10, s. 52)

As a result of Christian influence, the Udmurts began to address to Jesus Christ:

Я, Инмаре-Кристосэ, туж та секыт висёнэз но мынам басьтэме потэ, бордысьтыз келяме потэ. Кызьы ке но басьты та адями котырысь та секыт висёнэз!

Inmar-Christ, I am eager to take this severe disease away [from the patient]. In some way or other take this severe disease from this person! (FD UdSU 1999/2000 L. Maksimova, p. 33) 
The illness/disease was thought to have its own special place. This idea is found in the following well-known formula:

Шунды бертэм,
Толэзь бертэм,
Нунал бертэм,
Кизили бертэм.
Озыы ик та но мед бертоз.
Эмыз-юмыз мед та луоз. Мед йӧналоз.

The sun has come back, The moon has come back, A day has come back, A star has come back

May this [boil, furuncle] come back too.

May it [the charm] be medicine/cure. May the patient recover. (Archive of UIHLL f. 762, c. 18, s. 17)

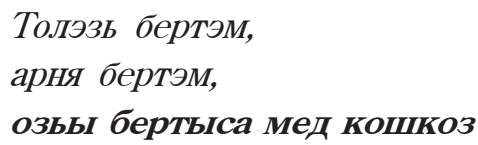

The moon has come back home, The week has come back home, That way may the disease come back home (Mikheev 1926: 44)

\section{Шунды бертэм, \\ Нунал бертэм, \\ Кизили бертэм, \\ Толэзь бертэм -}

\section{Мед бертоз йыдые синмысьтым!}

The sun has come back, A day has come back, A star has come back, The moon has come back -

\section{May my sty (hordeolum) come back home!}

(Kel'makov 1981: 42)

The presented formula emphasise the established order in the world and cyclic recurrence of natural processes. The illnesses/diseases (their spirits) entering the human body disturb the harmony of the world and are therefore forced to return back their original space - the beyond. 
The idea of considering the illness/disease as a representative of the other world is proved by the established concept: the illness can be sent away by water of a river:

Уян пырыку эмняно, кийын кыскаса, таӥе кыллёс вераса (ум пушкын гынэ): "Ву кузя берты, пень кай, тузон каӟ куасьмыса быры!”

When an illness/disease enters [the human body], it is treated by way of massaging and whispering the following words: "With the water return [home], like ashes, like dust dry and disappear!" (FDA UdSU 2000/ 2001 M. Nabieva, p. 4)

\section{Седэз, азьтэмез вуя мед кошкоз, урод сямыд мед быроз!}

May all your blackness [everything that is bad, poor] and laziness go away with the water, may your bad temper disappear! (FDA UdSU 2001/2002 L. Kuzmina, p. 15)

Та дун ву сямен ик жыльыртыса, бызись вуя мед кошкоз син усемез, медаз бӧрды ни Олёша, мед таза, чебер будоз.

As this clear water murmurs, may his evil eye go away with the running water, may Alex not cry any more, may he be healthy and handsome. (FDA UdSU 1996/1997 E. Ziyatdinova, p. 6)

Куасьмылысьтэм мумыёс! [here: Чупчи мумы, Пызеп мумы, шур мумыёс] Ву бӧрсяд келялэ котьмар чердэс!

Never drying mothers! [here: mother of the Cheptsa river, mother of the Pyzep river] With your water send away all severe illnesses/ diseases! (Wichmann 1893: 134)

In many mythologies the river is known as a symbol of a special route to the beyond, the way which connects the quick and the dead (Slovar simvolov 2006: 167; Slavianskie drevnosti 2009: 416). The Udmurts associated the water/river with the lower part of the triform structure of the world (Vladykin 1994: 75) and believed that the souls of the dead were supposed to leave this world along the river (Vladykin 1994: 75). Thus, the water, or the river, taking away the illnesses and diseases to the other world would help to clean this space from evil spirits and, by way of this, treat a patient.

The disease can be sent away not only with the water, but also with the wind: ... озьы ик та висёнме но мед нуоз тӧл сьӧры' '...may the wind take away my illness, too' (Vereshchagin 2000: 29), or with the smoke: Кинлэсь кышкад, пие, пунылэсь-а, ӟазеглэсь-а яке кинлэсь ке, та ӥын сьцраз мед 
басьтоз вань кышкамъёстэ 'Who you have been frightened of, my son, whether a dog, whether a goose or somebody else, may this smoke take away all your fear' (Archive of UIHLL f. 742, c. 6, s. 5) (see about fumigation: Chirkova 2009: 262-265).

As mentioned above, the Udmurts interpreted the illness as a hostile being living in the other world. This territory is presented in the Udmurt healing charms as the space which is located beyond the bounds of the forest:

Синме потэм йыдыез эмъяло вылэм пересьёс тазьы: “Шунды бертэм, нунал бертэм, кизили бертэм, толэзь бертэм, мед йыдыед быроз, кыдёке сик сьӧры кошкоз!”

The old treated the sty the following way: "The sun has come back home, a day has come back home, a star has come back, the moon has come back, may your sty disappear, far beyond the forest go!" (FDA UdSU 2001/2002 O. Strelkova, pp. 7-8).

The Udmurt prayers refer to the places to where one can conceivably send the illness away:

Гуртэ пырысь через-чурез тузонэз сяин, лысвуэз сяин нюлэс сьӧры, чабы сьӧры лэзьысалӥд ке...

If you threw away the illness, coming into the village, as dust, as dew if you threw it away beyond the wood, beyond the hedge ... [of a special sacral place for praying] (Munkácsi 1887: 163)

As we can see illnesses could be sent beyond the forest, and the border between this and the other world could be a special hedge made of branches of conifers. Such hedges were made by the Udmurts only around the sacral places for praying in the forest (Vasil'ev 1906: 186).

In the Udmurt sacral texts the beyond was presented also as a territory beyond the field: Котькӧие дышмонэз бусы сьӧртӥ лэзь ('Let every enemy pass beyond the field') (Wichmann 1893: 131), under the bath-house (banya) benches: Ведӥнъёс, сьӧд синмын учкисьёс лапча сьӧры мед кошкозы ('Мау evil sorcerers and those who have put their evil eyes go under the bathhouse (banya) benches') (FDA UdSU 2000/2001 E. Vasil'eva, p. 11). The healing sorcerer could also order the disease to leave the body and go away along a road, a river or a fence: Сюрес кузя, ву кузя, кенер кузя мед кошкоз ('Мау it go away along a road, a river, or a fence') (Minniiakhmetova 2003: 58). These places can be regarded as ones where illnesses are sent to as they can exist there. The Udmurts also believed that in those places one could catch a disease. 
It is significant that in the Udmurt healing charms and prayers "the beyond" is not described in detail but only its location is indicated (downstream the river, beyond the wood, the hedge, the field, etc.), whereas the healing texts of eastern Slavic peoples describe the other world more carefully: the beyond is shown as an exact antithesis of this world (Sveshnikova 1993: 142).

Illnesses and diseases can be dispatched not only to the other world - their original place of living, but also to the tree or wood which was considered as a substitute of a human soul. It is remarkable that such a way of getting rid of an illness is typical of only three functional groups of Udmurt healing charms: the texts for treating furuncles/boils, a sore throat/tonsillitis and agnail/panaritium:

Кӧс ньылос потэм, та кӧс писпу борды мед кылёз. Эмез-юмез та мед луоз.

A dry throat occurred, may it stay on this dry tree. May this [these words] medicine/drug be. (FDA UdSU 1997/1998 A. Spiridonova, p. 20)

Гижнисийисез эмъяку, висись чиньыез кор пылиськем вискы мырылоно. Озь мырылыку, таӥе кылъёс верано: “Шунды бертэм, нунал бертэм, кизили бертэм. Тань, Валялэсь гижнисийисьсэ эмъясько. Та гижнисийисьсэз кор вискы мед кылёз.”

While treating agnail/panaritium one should poke his/her finger into a log crack. At the same time one should say the following words: "The sun has returned, a day has returned, stars have returned. I am healing Valya's agnail. May this agnail in the log remain." (FDA UdSU 1992/ 1993 T. Volkova, p. 37)

The study of Udmurt charms shows that it was not always necessary to expel the illness to a special place, in some cases it was just enough to separate it from the human body:

Инмаре-Кылчинэ, батюшкое, кызьы ке тон мыным юртты та адями котырысь черъёсты улляны, та адямиез мынам висъяме потэ.

Inmar-Kylchin, father, somehow help me to expel the illnesses from this person, I want to separate him/her [from the illness]. (FDA UdSU 1999/ 2000 L. Maksimova, pp. 31-32)

Абадан, гызег, та верам кылбур эмез-юмез та медло! Пуртэн-тӥрен вӧлса бордысьтыз мед паласькоз!

Abadan, gyzeg [words swearing the illness], may the told words be the medicine/drug! Like with an axe and a knife shaved may the illness fall away! (Munkácsi 1952: 156-157) 
Та пурт кыӟы вӧлса басьтэ пуэз, оӟы ик вӧлса басьтйсько висёнзэ.

As this knife shaves wood, so I shave/separate the illness [from the patient]. (FDA UdSU 2002/2003 L. Komarova, p. 18)

Thus, the process of separating the illness/disease from a patient was equal to the process of healing.

In conclusion, it would be expedient to emphasise once more that separating the illness/disease and the patient's body and expelling the pathogenic spirits to the beyond was regarded as a magical influence with the use of thought/ word/act on the clinical process. Moreover, returning the illness to its original space symbolises the process of stabilising the world order.

\section{ABBREVIATIONS}

f. - file

s. - sheet

p. - page

c. - copybook

UIHLL - Udmurt Institute of History, Language and Literature (Russian Academy of Sciences, Ural Department)

FA UdSU - folklore archives of the Faculty of Udmurt Philology (Udmurt State University)

FDA UdSU - folklore and dialectological archives of the Faculty of Udmurt Philology (Udmurt State University)

$\mathrm{FE}$ - folklore expedition

\section{REFERENCES}

Chirkova, Ekaterina V. 2009. Okurivanie rebenka kak lechebnyi obriad. In: T. G. Vladykina (ed.-in-chief) Traditsionnaia kul'tura v izmeniaiushchemsia mire. Izhevsk, pp. 262-265.

Kel'makov, Valei K. 1981. Obraztsy udmurtskoi rechi $=$ Udmurt"eslen veras'kon siam"essy. Severnoe narechie $i$ sredinnye govory. Izhevsk: Udmurtiia.

Minniiakhmetova, Tatiana, G. 2003. Traditsionnye obriady zakamskikh udmurtov. Struktura. Semantika. Fol'klor. Dissertationes folkloristicae Universitatis Tartuensis 2. Tartu: Tartu University Press.

Mikheev, I. S. 1926. Bolezni i sposoby ikh lecheniia po verovaniiam $i$ obychaiam Kazanskikh votiakov. Votiaki. Sb. po voprosam ekonomiki, byta i kul'tury votiakov. Kniga 1. Moscow: Tsentr. Izd-vo narodov SSSR

Munkácsi, Bernát 1887. Votják Népköltészeti Hagyományok. Budapest: Magyar tudományos akadémia. 
Munkácsi, Bernát 1952. Volksbräuche und Volksdichtung der Wotjaken. Aus dem Nachlasse von Bernhard Munkácsi. Herausgegeben von D. R. Fuchs. Suomalais-Ugrilaisen Seuran Toimituksia 102. Helsinki: Suomalais-Ugrilaisen Seura.

Nebzhegovskaia-Bartminskaia, Stanislava 2005. Shla boliachka s Bolentina... Kontseptualizatsiia bolezni v pol'skom iazyke i v pol'skikh narodnykh zagovorakh. In: Zagovornyi tekst. Genezis i struktura. Moscow: Indrik, pp. 309-325.

Nikitina, Galina A. 2003. Mifologicheskie predstavleniia v narodnoi meditsine udmurtov: Udmurtskaia mifologiia. Izhevsk, pp. 84-96.

Olupe, E. 1993. Formula unichtozheniia v latyshskikh zagovorakh. In: V. V. Ivanov \& T. N. Sveshnikova (eds.) Issledovaniia $v$ oblasti balto-slavianskoi dukhovnoi kul'tury. Zagovor. Moscow: Nauka, pp. 128-139.

Sveshnikova, T. N. 1993. Struktura vostochnoromanskogo zagovora v sopostavlenii s vostochnoslaviatnskim (formuly otsylki bolezni). In: V. V. Ivanov \& T. N. Sveshnikova Issledovaniia v oblasti balto-slavianskoi dukhovnoi kul'tury. Zagovor. Moscow: Nauka, pp. 39-149

Sveshnikova T. N. 1995. O nekotorykh tipakh zagovornykh formul. In: Malye formy fol'klora. Sbornik statei pamiati G.L. Permiakova. Moscow: Vostochnaia literatura, pp. 121-129.

Slavianskie drevnosti 2009 = Slavianskie drevnosti: etnolingvisticheskii slovar'v 5-ti tomakh. Edited by N. I. Tolstoi. T.4: P-S. Moscow: Mezhdunarodnye otnosheniia.

Slovar simvolov 2006 = Slovar' simvolov $i$ znakov. Compiled by V. V. Adamchik. Moscow: AST, Kharvest.

Vasil'ev, Ioann 1906. Obozrenie iazycheskikh obriadov, sueverii i verovanii votiakov Kazanskoi $i$ Viatskoi gubernii. Izvestiia Obshchestva arkheologii, istorii ietnografii. Kazan'. Vol. XXII, No. 3, pp. 185-219; No. 4, pp. 253-276; No. 5, pp. 321-349.

Vel'mezova, Ekaterina V. 1999. Semantika prostranstva lechebnogo zagovora: k tipologii formul otsylki bolezni (na primere vostochnoslavianskikh, cheshskikh i frantsuzskikh tekstov). Vestnik Moskovskogo universiteta. Filologiia, Seriia 9, No 4, pp. $50-60$.

Vel'mezova, Ekaterina V. 2000. Semantika prostranstva cheshskogo lechebnogo zagovora: formuly otsylki bolezni. Zhivaia starina, Vol. 1, pp. 35-36.

Vereshchagin, Grigorii E.2000. Sobranie sochinenii: Etnograficheskie ocherki. Kn. 2. Izhevsk: Udmurtskii institut istorii, iazyka i literatury Ural'skogo otdeleniia Rossiiskoi akademii nauk.

Vladykin Vladimir E. 1994. Religiozno-mifologicheskaia kartina mira udmurtov. Izhevsk: Udmurtiia.

Wichmann, Y. 1893. Wotjakische Sprachproben I. Lieder, Gebete und Zaubersprüche. Helsingfors.

Zaitseva, Elena N. 2004. Narodnaia meditsina udmurtov v kontse XIX-pervoi treti XX $v v$.: dissertatsiia na soiskanie uchenoi stepeni kandidata istoricheskikh nauk. Izhevsk. 